\title{
Optimum Steel Fiber Content of High Strength Pozzolime Concrete
}

\author{
Tareq S. Al-Attar ${ }^{\circledR}$, Ahmed Sh. J. Al-Zuheriy ${ }^{\circledR}$, Sabreen M. Hamza* \\ Civil Engineering Dept., University of Technology-Iraq, Alsina’a street,10066 Baghdad, Iraq. \\ *Corresponding author Email: bce.19.14@grad.uotechnology.edu.iq
}

\section{H I G H L I G H T S}

- Pozzolime concrete was reinforced with hooked-end steel fiber at $(0.5,1.0,1.5$, and 2) percent volume fractions.

- The presence of steel fibers has a significant negative effect on the workability of all volume fractions tested.

- The maximum compressive and flexural strength was acquired, with the addition of 1.5 percent.

- The 1.5 percent volume fraction could be considered as the optimum fiber content.

\section{A R T I C L E I N F O}

\begin{tabular}{l} 
Handling editor: Wasan I. Khalil \\
\hline Keywords: \\
Compressive strength \\
Flexural strength \\
Hooked end steel fiber \\
Optimum Value \\
Steel fiber pozzolime reinforced concrete \\
Workability
\end{tabular}

\section{Introduction}

In recent years, global interest in sustainable constructional materials and environmentally friendly is grown. Therefore, there is a critical need for new alternative constructional-binders to replace conventional cement (e.g., Portland cement) [1]. Currently, researchers are being encouraged to consider further options, one of which is the re-adopt of lime-Pozzolana systems. Lime could be regarded as an environmentally-sound binder because of its low energy requirements, minimal $\mathrm{CO}_{2}$ emissions during manufacturing, and $\mathrm{CO}_{2}$ preoccupation via carbonation during setting [2]. Lime-natural Pozzolana is a building material was used in masonry a long time ago [3]. Due to their slow setting and hardening, the usage of lime-natural pozzolana has been discontinued throughout the history of inorganic binders. Since Portland cement are quick to set and had high strength in the early ages, utilization of natural pozzolan-lime binding material was drastically reduced after its invention in the 19th century. In the last 50 years, the environmental consequences of the Portland cement manufacturing process had prompted an increase in interest in lime-natural pozzolan cement [4]. In Iraq Pozzolime, a novel sustainable binder made from hydrated lime, silica fume, and fly ash, has been developed by Kadum et al [5]. The conceptualize of Pozzolime is based on the pozzolanic reaction between supplementary cementations materials, SCM and calcium hydroxide to produce calcium silicate hydrates similar to that produced by Portland cement hydration. By the following equation, the Pozzolan reaction could be expressed:

$$
3 \mathrm{Ca}(\mathrm{OH}) 2+\mathrm{SiO} 2=3 \mathrm{CaO} \cdot \mathrm{SiO} 2+3 \mathrm{H} 2 \mathrm{O} \text { or } \mathrm{C} 3 \mathrm{~S} 2 \mathrm{H} 3
$$


Small and disconnected fibers were utilized for thousands of years to strengthen brittle materials. The Egyptians employed straws for instance in ancient times to enhance the crack resistance of sun-dried muds that were used to build huts [7]. The concept of incorporating steel fibers into concrete dates back to the 1800s when metallic waste was included in the mix [8]. The inclusion of steel reinforcing bars into concrete can prevent failure after crack and greatly increase the ductility and strength of the concrete material. Several studies have demonstrated that adding fibers, particularly steel fibers, to reinforced concrete can decrease or perhaps even eliminate the need for traditional primary reinforcement in some situations [9,10,11]. Steel fibers have been shown to increase post-cracking tensile response and crack control properties in reinforced concrete [12]. Mechanical strength of composite materials can also be increased by the use of deformed fibers, such as hooked, corrugated and twisted fibers. Deformed steel fibers reported can provide three to seven times greater fiber-matrix bond strength than that of straight fibers. The extent to which the mechanical characteristics are improved relies on several aspects such as fiber geometry, fiber length, cure conditions, and fiber length [13]. The fibers were often added to FRCC as a volumetric ratio (Vf) of the mix limited, up to $\%$, to overcome mixing and casting issues such as balling and floating of the fibres [14]. The SFRC concept is simple. Concrete is weak in tension and reinforcing bars are only continuous at some specific positions, the tensile response of conventionally reinforced concrete is increased only in the reinforcement direction. Steel fibers, however, are randomly and discontinuously dispersed these features allow cracks to be bridged through the fibers in any orientation and allow better stress transport through all cracks, and enhanced post-cracking shear and flexural resistance [9]. In addition, fiber bridging permits the control of crack openings to allow more cracks to form. As a result, crack width and spacing are reduced, improving post-cracked ductility and energy absorption capacity [9, 15, 16, and 17]. In tensile stress, SFRC only fails after the fracture in the fibre or is pulled from the matrix [18]. Compressive stress, like the tensile response, mainly enhances post-peak ductility and toughness with the addition of steel fibres [19]. As previously stated, despite the numerous advantages of steel fiber on cement-based materials, such as improving in mechanical performance, increase postcracking tensile response and controlling of crack of cement concrete, etc., however, the effects of steel fiber on new binders such pozzolimehas never been used before. Therefore, in order to get the additional information and to gain a better knowledge of the behavior of Fiber-reinforced Pozzolime concrete, this study aims to investigate the influence of the addition of hooked end steel fibers on its properties.

\section{Materials, Mixes and Methods}

\subsection{Materials}

The Silica fume and the Fly Ash were used as two kinds of materials for cementation. The chemical composition and physical properties of each material were determined following ASTM C1240 [20] and ASTM C 618 [21], respectively. Hydrated lime compatible with ASTM C821 [22] was used for the production of pozzolime. The chemical and physical characteristics of the material are shown in Table 1. To modify the workability of the Pozzolime concrete mixtures conforming to ASTMC494 [23] type F, high-range water-reducing admixture commercially known as Viscocrete- 5930 was used. In this experiment, a coarse aggregate with a maximum particle size of $14 \mathrm{~mm}$ and a fine aggregate with a 2.25 fineness modulus was used. The specific gravity and water absorption of course and fine aggregates were 2.65 and 0.05 percent, and 2.67 and 1.6 percent, respectively. Hooked-end steel fiber was used for this purpose. Table 2 lists the properties of the fiber used. The properties of steel fiber were in accordance with ASTM A820 [24].

Table 1: Chemical and physical properties of the binder materials

\begin{tabular}{|c|c|c|c|c|c|}
\hline No. & & property & $\mathrm{HL}^{*}$ & $\mathrm{SF}^{*}$ & FA* \\
\hline \multirow{9}{*}{1} & & $\mathrm{CaO}$ & 86.44 & 0.58 & 0.98 \\
\hline & & $\mathrm{SiO} 2$ & $\ldots \ldots$ & 94.58 & 65.65 \\
\hline & & $\mathrm{A} 12 \mathrm{O} 3$ & $\ldots \ldots$ & 0.1 & 17.69 \\
\hline & Oxide & $\mathrm{Fe} 2 \mathrm{O} 3$ & $\ldots \ldots$ & 0.06 & 5.98 \\
\hline & content $\%$ & $\mathrm{MgO}$ & 3.25 & 0.22 & 0.72 \\
\hline & & $\mathrm{SO} 3$ & & 0.11 & 0.19 \\
\hline & & $\mathrm{Na} 2 \mathrm{O}$ & & 0.21 & 1.35 \\
\hline & & $\mathrm{K} 2 \mathrm{O}$ & & 0.35 & 2.99 \\
\hline & & L.O.I & & 1.98 & 3.1 \\
\hline 2 & $\begin{array}{l}\text { Surface Area } \\
\text { (Blaine)m2 }\end{array}$ & & 1200 & 20000 & 773 \\
\hline
\end{tabular}

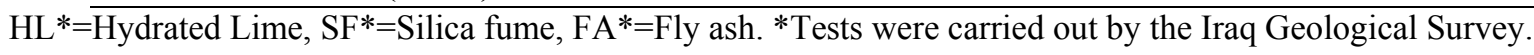

Table 2: Hooked-end steel fiber features

\begin{tabular}{lllllll}
\hline Property & $\begin{array}{l}\text { Length, } \\
\mathrm{mm}\end{array}$ & $\begin{array}{l}\text { Diameter, } \\
\mathrm{mm}\end{array}$ & $\begin{array}{l}\text { Aspect } \\
\text { ratio1/d }\end{array}$ & $\begin{array}{l}\text { Density, } \\
\mathrm{kg} / \mathrm{m} 3\end{array}$ & $\begin{array}{l}\text { Tensile } \\
\text { Strength, } \\
\mathrm{MPa}\end{array}$ & $\begin{array}{l}\text { Modulus of } \\
\text { Elasticity, GPA }\end{array}$ \\
\hline Value & 35 & 0.6 & 58 & 7800 & 1000 & 203 \\
\hline
\end{tabular}

*As given by manufacturer /Hebei Yusen Metal Wire Mesh Co., Ltd. 


\subsection{Pozzolime mixtures}

A reference mix, M0, was produced with 1: 1 by weight Lime to Pozzolana ratio. Table 3 lists the mixed details. The fourvolume percentages of hooked-end steel fibers were strengthened to provide mixtures: $0.5,1,1.5$ and 2 percent, respectively M0.5, M1.0, M1.5, and M2.0.

Table 3: Detail of mixtures

\begin{tabular}{|c|c|c|c|c|c|c|c|c|c|c|}
\hline \multirow[t]{2}{*}{ Mix } & \multicolumn{3}{|c|}{ Binder, kg/m3 } & \multicolumn{2}{|c|}{ Aggregate, kg/m3 } & \multirow{2}{*}{$\begin{array}{l}\text { Water, } \\
\mathrm{kg} / \mathrm{m} 3\end{array}$} & \multirow{2}{*}{$\begin{array}{l}\text { Steel fiber, } \\
\mathrm{kg} / \mathrm{m} 3\end{array}$} & \multirow{2}{*}{$\begin{array}{l}\text { W/B } \\
\text { By } \\
\text { wt }\end{array}$} & \multirow{2}{*}{$\begin{array}{l}\text { HRWR } \\
\text { by wt } \\
\text { of } \\
\text { binder }\end{array}$} & \multirow[t]{2}{*}{ Vf\% } \\
\hline & HL* & $\mathbf{S F}^{*}$ & FA* & Fine & Coarse & & & & & \\
\hline $\mathrm{M}_{0.0}$ & 200 & 120 & 80 & 640 & 960 & 152 & 0.0 & 0.38 & 1.65 & 0.0 \\
\hline $\mathrm{M}_{0.5}$ & 200 & 120 & 80 & 640 & 960 & 152 & 39.25 & 0.38 & 1.77 & 0.5 \\
\hline $\mathrm{M}_{1.0}$ & 200 & 120 & 80 & 640 & 960 & 152 & 78.5 & 0.38 & 1.85 & 1.0 \\
\hline $\mathrm{M}_{1.5}$ & 200 & 120 & 80 & 640 & 960 & 152 & 117.75 & 0.38 & 1.90 & 1.5 \\
\hline $\mathrm{M}_{2.0}$ & 200 & 120 & 80 & 640 & 960 & 152 & 157 & 0.38 & 2.00 & 2.0 \\
\hline
\end{tabular}

$\mathrm{HL}^{*}=$ hydrated lime, $\mathrm{SF}^{*}=$ silica fume, $\mathrm{FA}^{*}=$ fly ash

\subsection{Testing program}

Table 4 shows the carried-out tests according to the shown standard methods, types of specimen, and age of test for the fresh and hardened Pozzolime mixtures.

Table 4: Fresh and hardened Pozzolime concrete tests

\begin{tabular}{lllll}
\hline Test & Adopted standard & $\begin{array}{l}\text { Specimen } \\
\text { type }\end{array}$ & Dimensions, mm & $\begin{array}{l}\text { Age of test, } \\
\text { days }\end{array}$ \\
\hline $\begin{array}{l}\text { Slump } \\
\text { Compressive Strength }\end{array}$ & ASTM C143 [25] & --- & ---- & -14, \\
& BS EN 12390-3 [26] & Cube & $100 * 100 * 100$ & $\begin{array}{l}14,28,56 \text { and } \\
90\end{array}$ \\
Flexural Strength & ASTM C78 [27] & Prism & $400 * 100 * 100$ & 14,28 and 90 \\
\hline
\end{tabular}

\section{Results and Discussion}

\subsection{Workability}

The slump test was carried out on fresh mixes to investigate the effect of steel fiber reinforcement on the workability of Pozzolime concrete. Figure 1 illustrates the average slump values. It is obvious to see that a $139 \mathrm{~mm}$ slump was recorded when no fibers were added into the Pozzolime concrete, $\operatorname{mix} \mathbf{M}_{\mathbf{0 . 0}}$. The slump values started to decrease when steel fibers were added for mixes $\mathrm{M}_{\mathbf{0 . 5}}, \mathrm{M}_{\mathbf{1 . 0}}, \mathrm{M}_{\mathbf{1 . 5}}$, and $\mathrm{M}_{\mathbf{2 . 0}}$. The reductions in slump value concerning $\mathrm{M}_{\mathbf{0 . 0}}$ were; $10,16.5,23$, and $29.5 \%$ respectively. The loss in a slump is mainly due to increased internal friction of ingredients and the balling of fibers. It is worth mentioning that this slump loss took place despite the dosage of HRWR was being increased.

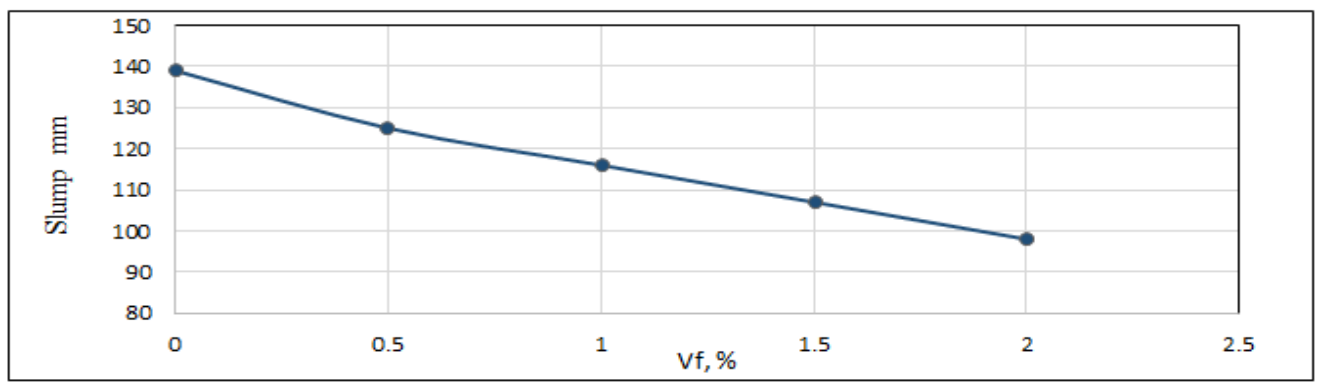

Figure 1: Effect of steel fibres on a slump of Pozzolime concrete mixtures

\subsection{Compressive Strength}

The compressive strength of Pozzolime concrete with and without being reinforced with steel fibers are listed in Table5 and shown in Figure 2. 
Table 5: Results from compressive strength for studied Pozzolime concrete mixes

\begin{tabular}{|c|c|c|c|c|c|c|c|c|c|}
\hline \multirow{2}{*}{ Mix } & \multirow{2}{*}{$\begin{array}{l}\text { Volume } \\
\text { fraction } \\
\text { of fiber, } \\
\text { Vf }\end{array}$} & \multicolumn{4}{|c|}{ Compressive strength MPa, at age: } & \multicolumn{4}{|c|}{ The ratio strength gain, $\%$ for age: } \\
\hline & & $14 d$ & $28 \mathrm{~d}$ & $56 \mathrm{~d}$ & $90 \mathrm{~d}$ & $14 d$ & $28 \mathrm{~d}$ & $56 \mathrm{~d}$ & $90 \mathrm{~d}$ \\
\hline $\mathrm{M}_{0.0}$ & 0.0 & 38.8 & 42.6 & 45.2 & 48.9 & ---- & ---- & ---- & ---- \\
\hline $\mathrm{M}_{0.5}$ & 0.5 & 48.5 & 50.4 & 51.3 & 53.2 & 25.0 & 18.3 & 13.5 & 7.2 \\
\hline $\mathrm{M}_{1.0}$ & 1.0 & 50.6 & 56.7 & 58.9 & 63.1 & 30.4 & 33.1 & 29.4 & 22.9 \\
\hline $\mathrm{M}_{1.5}$ & 1.5 & 66.5 & 72.7 & 75.8 & 78.9 & 71.4 & $v \cdot .7$ & 67.3 & 58.3 \\
\hline $\mathrm{M}_{2.0}$ & 2.0 & 58.4 & 65.6 & 68.8 & 70.6 & 50.5 & 53.9 & 48.7 & 42.3 \\
\hline
\end{tabular}

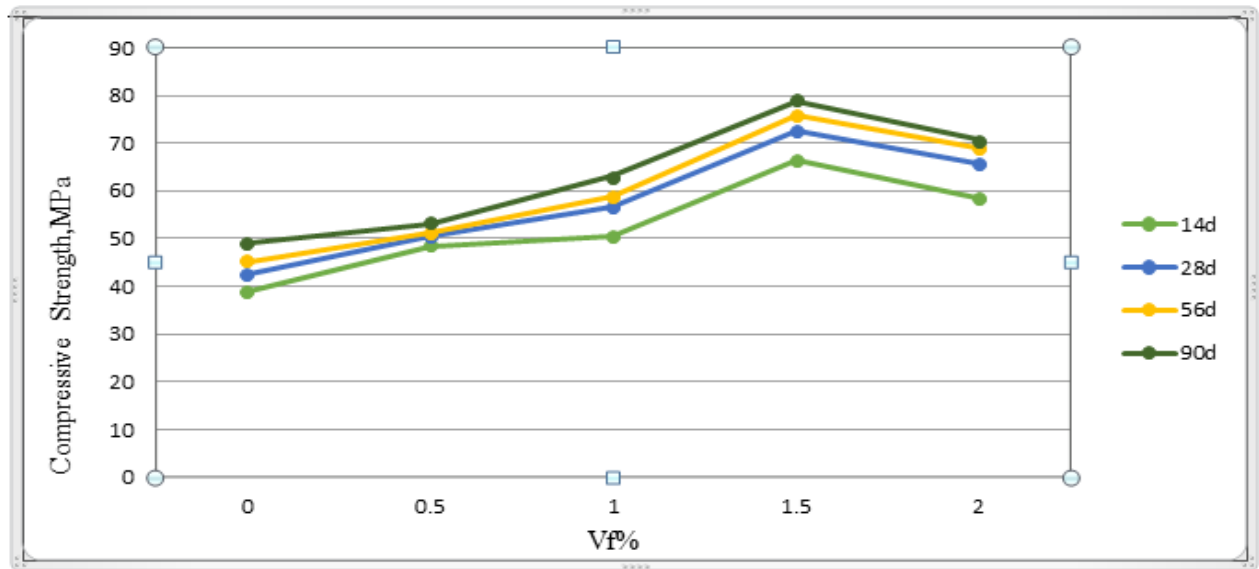

Figure 2: Influence of steel fibres on the compressive strength of pozzolime concrete

According to Table 5, it can be observed that there is always a gain in compressive strength with the increase in fiber content. This increase is understandable due to the higher density of steel added to concrete and caused more densification of the composite. Moreover, the inclusion of fibers was more effective in improving strength at an early age, 14 days, than other ages for all fiber contents. The gain in strength ratio is the increase in strength of fiber-reinforced mixes to the strength of reference mix M0, non-fibrous, at the specified age. Based on this ratio, it can be concluded the mix M1.5, which has Vf $=1.5 \%$, has shown the highest compressive strength increase at all ages. On the other hand, Mix M2.0, which has a higher Vf, exhibited a lower gain ratio and that could have resulted from the higher loss of workability which means higher content of entrapped air. Also, the higher possibility of fiber balling and improper bonding could be another reason.

\subsection{Flexural Strength}

The results of the flexural strength test on Pozzolime prism specimens are displayed in Table 6 and Figure 3 . The same trend that was outlined for compressive strength is observed here. Mix $\mathrm{M}_{1.5}$ also showed the highest gain in flexural strength ratio for all test ages. Therefore, this volume fraction could be considered the optimum fiber content that yields the best improvement concerning strength. In general, the inclusion of fibers in Pozzolime mixes caused a better enhancement in flexural strength results than those of compressive ones. This observation indicates that the role of fibers here is not the only densification but also crack arresting.

Table 6: Results of flexural strength for studied Pozzolime concrete mixes

\begin{tabular}{|c|c|c|c|c|c|c|c|}
\hline \multirow{2}{*}{ Mix } & \multirow{2}{*}{$\begin{array}{l}\text { Volume } \\
\text { fraction } \\
\text { of fiber, } \\
\text { Vf }\end{array}$} & \multicolumn{3}{|c|}{ Flexural strength MPa, at age: } & \multicolumn{3}{|c|}{ The ratio strength gain, $\%$ for age: } \\
\hline & & $14 d$ & $28 \mathrm{~d}$ & $90 \mathrm{~d}$ & $14 d$ & $28 \mathrm{~d}$ & $90 \mathrm{~d}$ \\
\hline M0.0 & 0.0 & 2.7 & 3.1 & 3.5 & ---- & ---- & ---- \\
\hline M0.5 & 0.5 & 3.5 & 5.0 & 5.8 & 29.6 & 61.3 & 65.7 \\
\hline M1.0 & 1.0 & 5.1 & 5.9 & 7.0 & 88.9 & 90.3 & 100 \\
\hline M1.5 & 1.5 & 7.3 & 9.4 & 10.2 & 170.4 & 203.2 & 191.4 \\
\hline M2.0 & 2.0 & 7.0 & 7.7 & 8.4 & 159.3 & 148.4 & 140 \\
\hline
\end{tabular}




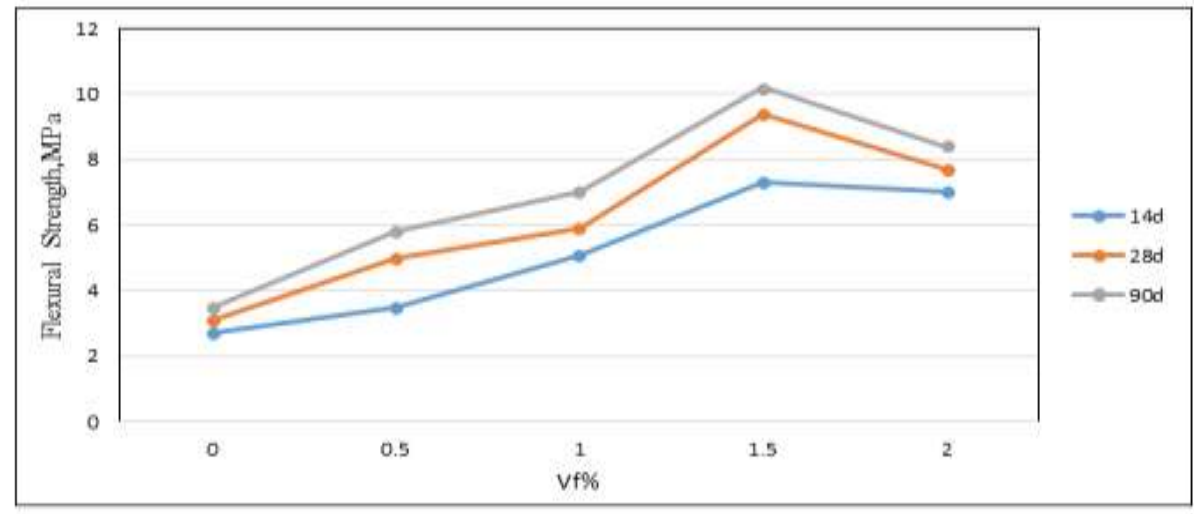

Figure 3: Influence of steel fibre on Pozzolime concrete's flexural strength

\section{Conclusions}

The following conclusions can be outlined based on the present data:

1) The steel fibers when used as reinforcement in Pozzolime concrete significantly reduce its workability. The slump values started to decrease when steel fibers were added for mixes according to [28] that conclude the inclusion of fibers (of any kind) reduced slump flow. It is worth mentioning that this slump loss took place despite the dosage of HRWR was being increased.

2) There is always a gain in strength with the increase in fiber content. The inclusion of fibers was more effective in improving strength at an early age, 14 days than other ages for all fiber contents.

3) The inclusion of fibers in Pozzolime mixes caused a better enhancement in flexural strength results than compressive strength results. These results indicate that fibers have a dual role in tensile stresses: densification and crack arrest.

4) Based on the gain in strength ratio, the $1.5 \%$ volume fraction could be considered as the optimum fiber content which yields the best improvement concerning strength.

\section{Author contribution}

All authors contributed equally to this work.

\section{Funding}

This research received no specific grant from any funding agency in the public, commercial, or not-for-profit sectors.

\section{Data availability statement}

The data that support the findings of this study are available on request from the corresponding author.

\section{Conflicts of interest}

The authors declare that there is no conflict of interest.

\section{References}

[1] F. Pacheco-Torgal, J. Castro-Gomes, and S. Jalali, Alkali-activated binders: A review. Part 1. Historical background, terminology, reaction mechanisms and hydration products, Constr. Build. Mater ., 22 (2008) 1305-1314. https://doi.org/10.1016/j.conbuildmat.2007.10.015

[2] A. J. Alsaad, T. S. Al-Attar, and B. S. Al-Shathr, Utilization of Mineral Sequestration for CO2 Capturing in Car Parks and Tunnels, Eng. Technol. J., 38 (2020). https://doi.org/10.30684/etj.v38i5a.594

[3] D. Saleh Al-Attar, B. Salah Mehdi, and M. Frayyeh Hattab, EFFECT OF EXTERNAL SULPHATES ON PROPERTIES OF LIME-POZOLANA CONCRETE, J. Eng. Sustain. Dev., 23 (2019). https://doi.org/10.31272/jeasd.23.5.4

[4] A. Moropoulou, A. Cakmak, K. C. Labropoulos, R. Van Grieken, and K. Torfs, Accelerated microstructural evolution of a calcium-silicate-hydrate (C-S-H) phase in pozzolanic pastes using fine siliceous sources: Comparison with historic pozzolanic mortars, Cem. Concr. Res., 34 (2004) 1-6. https://doi.org/10.1016/S0008-8846(03)00187-X.

[5] N. Kadum, T. Al-Attar, and Z. Al-Azzawi, Evaluation of pozzolime mixtures as a sustainable binder to replace portland cement in structural concrete, in MATEC Web of Conferences, 120 (2017) https://doi.org/10.1051/matecconf/201712002009 
[6] N. Saikia and J. de Brito, Use of industrial waste and municipality solid waste as aggregate, filler or fiber in cement mortar and concrete, in Municipal Solid Waste, (2012).

[7] [A. Meda, F. Minelli, G. A. Plizzari, and P. Riva, Shear behaviour of steel fibre reinforced concrete beams, Mater. Struct. Constr., 38 (2005) 277. https://doi.org/10.1617/14112

[8] M. A. Mansur, K. C. G. Ong, and P. Paramasivam, Shear Strength of Fibrous Concrete Beams Without Stirrups, J. Struct. Eng., 112 (1986) 2066-2079. https://doi.org/10.1061/(ASCE)0733-9445(1986)112:9(2066)

[9] J. Susetyo, P. Gauvreau, and F. J. Vecchio, Effectiveness of steel fiber as minimum shear reinforcement, ACI. Struct. J., 109 (2012) 426-428.

[10] L. Daniel and A. Loukili, Behavior of High Strength Fiber-Reinforced Concrete beams under cyclic loading, Struct. J., 99 (2002) 248-256. https://doi.org/10.14359/11908

[11] R. D. Lequesne, M. Setkit, G. J. Parra-Montesinos, and J. K. Wight, Seismic Detailing and Behavior of Coupling Beams With High-Performance Fiber Reinforced Concrete, (2010).

[12] S. P. Shah and B. V. Rangan, Fiber Reinforced Concrete Properties, J. Proc., 68 (1971) 126-137, https://doi.org/10.14359/11299

[13] Z. Wu, C. Shi, and K. H. Khayat, Investigation of mechanical properties and shrinkage of ultra-high performance concrete: Influence of steel fiber content and shape, Compos. Part B Eng., 174 (2019) 107021. https://doi.org/ $\underline{\text { 10.1016/J.COMPOSITESB.2019.107021 }}$

[14] G. K. Mohammed, K. F. Sarsam, and I. N. Gorgis, Flexural Performance of Reinforced Concrete Built-up Beams with SIFCON, Eng. Technol. J., 38 (2020) 669-680. https://doi.org/10.30684/ETJ.V38I5A.501

[15] Fiber-Reinforced Cements and Concretes - Colin D Johnston - Google Books.

[16] M. Grzybowski and S. P. Shah, Shrinkage Cracking of Fiber Reinforced Concrete, Mater. J., 87 (1990) $138-148$. https://doi.org/ 10.14359/1951

[17] J. R. Deluce and F. J. Vecchio, Cracking Behavior of Steel Fiber-Reinforced Concrete Members Containing Conventional Reinforcement, ACI. Struct. J., 110.

[18] ACI Comite 544, State of the Art Report on Fiber Reinforced Concrete Reported (ACI 544.1R-96 Reapproved 2002), ACI. Struct. J., 96 (2002) Reapproved.

[19] J. Thomas and A. Ramaswamy, Mechanical Properties of Steel Fiber-Reinforced Concrete, J. Mater. Civ. Eng., 19 (2007) 385-392. https://doi.org/10.1061/(ASCE)0899-1561(2007)19:5(385)

[20] ASTM C 1240/C 1240M - 05, Standard Specification for Silica Fume Used in Cementitious Mixtures, ASTM. Int., (2005).

[21] ASTM 618, Standard Specification for Coal Fly Ash and Raw or Calcined Natural Pozzolan for Use in Concrete, Annu. B. ASTM. Stand., (2005).

[22] ASTM, Standard Specification for Lime for Use with Pozzolans, ASTM C821 - 14, 78 (2014) Reapproved.

[23] ASTM C494, Standard Specification for Chemical Admixtures for Concrete, ASTM Int., (2015) 1-10. https://doi.org/ $\underline{10.1520 / \mathrm{C} 0494}$

[24] S. Fibers and F. Concrete, A 820/A 820M-04 Standard Specification for steel fibers for fiber-reinforced concrete, ASTM , (2004).

[25] ASTM C143/C143M, Standard Test Method for Slump of Hydraulic-Cement Concrete, Astm C143, no. 1, (2015).

[26] BS EN 12390-2019 Part 3, testing hardened concrete: Compressive strength of test specimens, Br. Stand. Inst., (2019).

[27] ASTM International, Astm C78/C78M - 02: Stand. Test Method Flexural Strength Concr. (Using Simple Beam with Third-Point Loading)ASTM Int. USA, 04.02 (2002).

[28] T. S. Al-Attar, S. F. Daoud, and A. S. Dhaher, Workability of Hybrid Fiber Reinforced Self-Compacting Concrete, Eng. Technol. J., $36 \quad$ (2018), Accessed: Jul. 30, 2021. [Online]. Available: https://mail.engtechjournal.org/index.php/et/article/view/131 